\title{
Maternal socio-demographic and economic factors of preterm babies born in Teaching Hospital, Jaffna, Sri Lanka
}

\author{
*Sasrubi Sathees ${ }^{1}$, Manoji Gitanjali Sathiadas ${ }^{2}$, Rajendra Surenthirakumaran ${ }^{3}$, Vasanthy Arasaratnam ${ }^{1}$ \\ Sri Lanka Journal of Child Health, 2021; 50(4): 692-698 \\ DOI: http://doi.org/10.4038/sljch.v50i4.9889
}

\begin{abstract}
Background: Several maternal, socio-demographic and economic characteristics are associated with preterm birth.
\end{abstract}

Objectives: To assess the influence of maternal socio-demographic and economic factors on preterm deliveries in Jaffna, Sri Lanka.

Method: This is an institutional based prospective descriptive study conducted at the Teaching Hospital, Jaffna, Sri Lanka, from October 2015 to February 2017. A pre-tested questionnaire was used to study the association of maternal sociodemographic factors such as age, religion, marital status, education, and economic factors, such as employment, monthly income per person, and family type, to preterm deliveries. Preterm birth was categorized based on gestational age as very preterm ( 28 to $<32$ weeks) and moderate to late preterm (32 to $<37$ weeks). Data were entered and analysed using SPSS version 16.0.

Results: In our study $54.3 \%$ of preterm babies were males. Mean gestational age of the preterm babies was $35.0 \pm 1.9$ weeks. Frequency of moderate to late preterm delivery was $91.9 \%(n=159)$. Mean birth weight of the preterm babies was $2.2 \pm 0.6 \mathrm{~kg}$ with the range from 0.8 to $4.2 \mathrm{~kg}$. Of the mothers of the preterm babies $84.4 \%$ were 20 - 34 years old, $72.3 \%$ were Hindus, $98.8 \%$ were legally married, $39.9 \%$ studied up to Grade $11,86.1 \%$ were housewives, $62.4 \%$ received monthly income per

${ }^{1}$ Department of Biochemistry, ${ }^{2}$ Department of Paediatrics, ${ }^{3}$ Department of Community and Family Medicine, Faculty of Medicine, University of Jaffna, Sri Lanka

*Correspondence: sasrubi.sathees@gmail.com

iD, https://orcid.org/0000-0002-5324-3183

(Received on 17 October 2020: Accepted after revision on 21 January 2021)

The authors declare that there are no conflicts of interest.

Funding: Funded by the National Science Foundation, Sri Lanka (NSF/SCH/2018/01)

Open Access Article published under the Creative

Commons Attribution CC-BY CC (i) License person more than 4,340 Sri Lankan rupees (LKR) and $75.7 \%$ were living in extended family structure. No statistically significant association was found between maternal socio-demographic factors, economic status and gestational age of the preterm babies.

Conclusion: Maternal socio-demographic and economic factors had no significant influence on preterm deliveries in the Jaffna district of Sri Lanka.

(Key words: Socio-demographic status, Economic status, Very preterm, Moderate to late preterm)

\section{Introduction}

Preterm birth is birth occurring before 37 completed weeks of gestation ${ }^{1}$. Rate of preterm birth ranges from 5 to $18 \%$ globally ${ }^{2}$. Furthermore, $60 \%$ of these preterm births occur in Africa and South $\mathrm{Asia}^{3}$. About $45-50 \%$ of preterm births are idiopathic, $30 \%$ are related to preterm rupture of membranes and 15-20\% are elective ${ }^{3}$. Several factors are associated with preterm births, such as socio-demographic (maternal age below 16 and above 35 years, religion, ethnicity and educational level) and socioeconomic status (assessed using family income, employment and family type $)^{4}$. Approximately 24,500 babies are born premature annually in Sri Lanka ${ }^{5}$. Despite advances of neonatal and obstetric care practices in Sri Lanka, the preterm birth rate in Sri Lanka still ranges from 10-15 per 1000 live births ${ }^{5}$.

\section{Objective}

To assess the influence of maternal sociodemographic and economic factors on preterm deliveries in Jaffna, Sri Lanka.

\section{Method}

A prospective descriptive study was conducted in Teaching Hospital, Jaffna (THJ), Sri Lanka from October 2015 to February 2017 among babies born between $28^{+1}$ and $36^{+6}$ weeks of gestation. Preterm birth was categorized based on gestational age as very preterm ( 28 to $<32$ weeks) and moderate to late preterm $(32 \text { to }<37 \text { weeks })^{3}$. THJ is a tertiary care centre providing perinatal care services and special neonatal care. The government is the 
principal healthcare provider and all health services are free.

Sample size was calculated by the symptom prevalence $(11.5 \%)$ of Retinopathy of Prematurity (ROP) in a national study using the Daniel ${ }^{6}$ formula and the ' $p$ ' is $11.5 \%$ according to Kiridana et $a l^{7}$. Level of confidence was $95 \%$ with $\mathrm{z}$ being 1.96 and the non- response rate was $10 \%$. This led to a total sample size of 170 . The mothers who were residing in Jaffna RDHS area, and delivered preterm babies in THJ were recruited for this study. The mothers who could be selected under inclusion criteria, and gave their consent were considered as sample of this study. The dysmorphic preterm babies were excluded from this study.

Pre-tested interviewer-administered questionnaire was used as the study instrument. Questionnaire included questions on socio-demographic (age, religion, marital status, education), and economic status of mother (employment, monthly income per person, and family type), and birth profile of preterm babies (gender, and birth weight).

Based on mother's Last Regular Menstrual Period (LRMP), the gestational age was calculated as it was on the delivery date. Birth weight of the preterm babies was categorized as extremely low birth weight $($ ELBW) $(<1000 \mathrm{~g})$, very low birth weight (VLBW) (1000-1500 g), low birth weight (LBW) (1500-2500 g) and normal birth weight (NBW) (more than $2500 \mathrm{~g})^{3}$.

Statistical analysis: Data were coded and entered in Statistical Package of Social Sciences (SPSS), version 16.0. The associations between categorical variables were analysed using Chi square test. In case of less number cells, Fisher Exact Test (FET) was used in place of Chi square test. $p<0.05$ was considered statistically significant.

Ethical issues: Approval for the study was obtained from the Ethics Review Committee, Faculty of Medicine, University of Jaffna, Sri Lanka (J/ ERC/ 14/ 58/ NDR/ 0113). Informed written consent was obtained from the parents or guardians of the preterm babies. Confidentiality and anonymity of all records were ensured.

\section{Results}

A total of 7325 live births occurred during the study period in THJ. According to the convenient sampling method, out of 408 preterm babies born between $28^{+1}$ and $36^{+6}$ weeks of gestation, 173 preterm were recruited. Table 1 shows the birth profile of the preterm babies.

Table 1: Birth profile of preterm babies $(n=173)$

\begin{tabular}{|l|c|c|c|c|}
\hline \multirow{2}{*}{ Variable } & \multicolumn{2}{c|}{ Very preterm babies } & \multicolumn{2}{c|}{ Moderate to late preterm babies } \\
\cline { 2 - 5 } & No. & $\%$ & No. & \% \\
\hline Gender & 8 & 57.1 & 86 & 54.1 \\
Male & 6 & 42.9 & 73 & 45.9 \\
Female & & & & \\
\hline Birth weight & 2 & 14.2 & 0 & 0.0 \\
Extremely low birth weight $(<1000 \mathrm{~g})$ & 6 & 42.9 & 11 & 5.0 \\
Very low birth weight $(1000-1499 \mathrm{~g})$ & 6 & 42.9 & 95 & 59.7 \\
Low birth weight $(1500-2500 \mathrm{~g})$ & 0 & 0.0 & 53 & 33.3 \\
Normal birth weight $(>2500 \mathrm{~g})$ & 14 & 100.0 & 159 & 100.0 \\
\hline Total & & & \\
\hline
\end{tabular}

Very preterm: born from $28^{+1}-31^{+6}$ weeks of gestation, Moderate to late preterm: born from $32^{+0}-36^{+6}$ weeks of gestation

The frequency of moderate to late preterm babies in the current study was $91.9 \%$ of whom $54.1 \%$ were males. Mean gestational age of the preterm babies was $35.0 \pm 1.9$ weeks. Mean birth weight of the preterm babies was $2.2 \pm 0.6 \mathrm{~kg}$ (range 0.8 to $4.2 \mathrm{~kg}$ ), while the mean birth weight of moderate to late preterm babies was $2.3 \pm 0.6 \mathrm{~kg}$ which was higher than the mean birth weight of the very preterm.

Table 2 shows the maternal socio-demographic and economic factors. The mean maternal age was 28.8 \pm 6.4 years, ranging from 17 to 45 years. All the mothers who delivered preterm babies were Tamils and majority were Hindus, and married. All the mothers of the preterm babies had studied at least up to grade five according to Sri Lankan curriculum. Majority were housewives, received household monthly income per person more than 4,340 Sri Lankan rupees (LKR) and were living in an extended family structure.

Table 3 shows the relationship between gestational age of the preterm babies and socio-demographic and economic factors related to the mother. Maternal socio-demographic and economic characteristics had no direct influence on the very preterm and moderate to late preterm deliveries which occurred in the Jaffna district. 
Table 2: Maternal socio-demographic and economic factors $(n=173)$

\begin{tabular}{|l|c|}
\hline \multicolumn{1}{|c|}{ Variable } & $\begin{array}{c}\text { Mothers } \\
\text { n (\%) }\end{array}$ \\
\hline Maternal age (years) & \\
$<20$ & $08(04.6)$ \\
$20-34$ & $146(84.4)$ \\
$35-49$ & $19(11.0)$ \\
\hline Religion & \\
Hindu & $125(72.3)$ \\
Christian & $48(27.7)$ \\
\hline Marital status & \\
Married & $171(98.8)$ \\
Unmarried & $02(01.2)$ \\
\hline Education & \\
Grade 1- 5 & $11(06.4)$ \\
Grade 6-10 & $58(33.5)$ \\
Grade 11 & $69(39.9)$ \\
Grade 12 & $19(11.0)$ \\
Degree or above & $16(09.2)$ \\
\hline Employment & \\
Employed & $24(13.9)$ \\
Housewives & $149(86.1)$ \\
\hline Monthly total income per person (LKR) & \\
$<4340$ & $65(37.6)$ \\
$\geq$ 4340 & $108(62.4)$ \\
\hline Family type & \\
Nuclear & $42(24.3)$ \\
Extended & $131(75.7)$ \\
\hline Theminimum expenditureper person per month to fulfi the
\end{tabular}

*The minimum expenditure per person per month to fulfil the basic needs in Jaffna district of Sri Lanka in 2017 was $4340 L_{K R}^{30}$. Hence, the low socio-economy was determined in the present study as 4,340 LKR

Table 3: Relationship between gestational age of the preterm babies and socio-demographic and economic factors related to the mother

\begin{tabular}{|c|c|c|c|}
\hline \multirow[t]{2}{*}{ Variable } & \multicolumn{2}{|c|}{ Preterm babies $(n=173)$} & \multirow[t]{2}{*}{ Chi squared (p-value) } \\
\hline & Very preterm & Moderate to late preterm & \\
\hline $\begin{array}{l}\text { Maternal age (years) } \\
<20 \\
\geq 20\end{array}$ & $\begin{array}{l}02(14.3) \\
12(85.7)\end{array}$ & $\begin{array}{c}06(03.8) \\
153(96.2)\end{array}$ & $\begin{array}{c}20.976 \\
(p=0.129, \text { FET })\end{array}$ \\
\hline $\begin{array}{l}\text { Religion } \\
\text { Hindu } \\
\text { Christian } \\
\end{array}$ & $\begin{array}{l}11(78.6) \\
03(21.4)\end{array}$ & $\begin{array}{l}114(71.7) \\
45(28.3)\end{array}$ & $\begin{array}{c}0,303 \\
(\mathrm{p}=0.760, \text { FET })\end{array}$ \\
\hline $\begin{array}{l}\text { Marital status } \\
\text { Married } \\
\text { Unmarried }\end{array}$ & $\begin{array}{c}14(100.0) \\
0(0)\end{array}$ & $\begin{array}{l}157(98.8) \\
02(01.2)\end{array}$ & 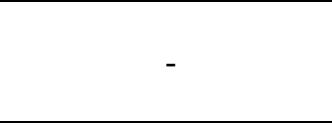 \\
\hline $\begin{array}{l}\text { Educational level } \\
\text { Below grade } 12 \\
\text { Grade } 12 \text { and above } \\
\end{array}$ & $\begin{array}{l}10(71.4) \\
04(28.6) \\
\end{array}$ & $\begin{array}{l}128(80.5) \\
31(19.5) \\
\end{array}$ & $\begin{array}{c}9.488 \\
(\mathrm{p}=0.486, \text { FET })\end{array}$ \\
\hline $\begin{array}{l}\text { Maternal employment } \\
\text { Yes } \\
\text { No }\end{array}$ & $\begin{array}{l}01(07.1) \\
13(92.9)\end{array}$ & $\begin{array}{c}23(15.7) \\
134(84.3) \\
\end{array}$ & $\begin{array}{c}0.742 \\
(p=0.697, \text { FET })\end{array}$ \\
\hline $\begin{array}{l}\text { Monthly income per } \\
\text { person (LKR) } \\
<4,340 \\
\geq 4,340\end{array}$ & $\begin{array}{l}07(50.0) \\
07(50.0)\end{array}$ & $\begin{array}{c}58(36.5) \\
101(63.5)\end{array}$ & $\begin{array}{c}1.003 \\
(p=0.391, \text { FET })\end{array}$ \\
\hline $\begin{array}{l}\text { Family type } \\
\text { Nuclear family } \\
\text { Extended family }\end{array}$ & $\begin{array}{l}04(28.6) \\
10(71.4)\end{array}$ & $\begin{array}{c}38(23.9) \\
121(76.1)\end{array}$ & $\begin{array}{c}0.153 \\
(p=0.747, \text { FET })\end{array}$ \\
\hline
\end{tabular}

FET-Fisher Exact Test value 


\section{Discussion}

This study aimed to find out the association of maternal socio-demographic and economic factors to very preterm deliveries and moderate to late preterm deliveries. However, paucity of data of very preterm deliveries has limited the interpretation between maternal factors and very preterm deliveries. Prevalence of moderate to late preterm babies in this current study was $91.9 \%$, and the ratio between very preterm to moderate to late preterm was $1: 11.4$, while worldwide prevalence of moderate to late preterm babies was $84 \%{ }^{9}$, and the ratio between very preterm to moderate to late preterm was $1: 2.5^{10}$. High prevalence of moderate to late preterm deliveries recorded in our study indicate that antenatal mothers attend the improved and free obstetric care available in Jaffna district of Sri Lanka. In the current study, mean gestational age of preterm babies from Jaffna district was 35.0 \pm 1.9 weeks, and it belonged to moderate to late preterm, similar to other studies ${ }^{10,11}$.

In this study, prevalence of very preterm babies was $8.1 \%(n=14)$. In a previous study in Jaffna district, Sri Lanka, in 2011, frequency of preterm birth was $4.9 \%$, and preterm babies were not being categorized $^{12}$. However, it was well observed in Gampaha district of Sri Lanka, where there was low frequency $(8.6 \%)$ of very preterm babies ${ }^{13}$. It may be that free and good quality antenatal care at earlier gestations allowed prolongation of pregnancies in Sri Lanka. Majority (54.3\%) of preterm babies in this study were male. It supported the finding that boys were more likely to be delivered preterm as illustrated by previous studies ${ }^{9-11,14-16}$. Several explanations have been proposed why pregnancies carrying male fetuses could have high risk of preterm birth, as boys are more likely to be conceived in the beginning of the fertile period in contrast to girls ${ }^{17}$, even though sex differentiation begins at conception ${ }^{14}$.

The mean birth weight of preterm babies belonged to LBW, and $59.7 \%$ of preterm babies were born with LBW. Similar to our findings, mean birth weight of preterm babies was of LBW in other countries $^{10,16,18}$. Weight of the fetus is gained during the latter part of pregnancy ${ }^{19}$. In this study too, the mean birth weight of moderate to late preterm babies $(2.3 \pm 0.6 \mathrm{~kg})$ was higher than very preterm $(1.4 \pm 0.4 \mathrm{~kg})$ babies indicating that the distribution of gestational age to birth weight resulted from an increase in gestational length of preterm babies.

The mean maternal age was $28.8 \pm 6.4$ years, ranging from 17 to 45 years, and was similar to a previous study ${ }^{18}$. Mean maternal age of moderate to late preterm babies was $28.2 \pm 5.6$ years with a range of 17-45 years, and it differed in other studies $^{9,16}$. Percentage of mothers aged $<20$ years who delivered preterm babies was $4.6 \%$ in this study and $13.2 \%$ in another study ${ }^{5}$, while $11.0 \%$ of the mothers aged $\geq 35$ years delivered preterm babies in current study and it was $14.4 \%{ }^{15}$ and $27.6 \%{ }^{20}$ in other studies. These findings indicate that the association between preterm babies and maternal age remains controversial. However, in the Jaffna district, $84.4 \%$ of the maternal population was between $20-34$ years and only $4.6 \%$ were $<20$ years (Table 2), which is similar to other parts of Sri Lanka ${ }^{8}$.

In this study all the mothers who delivered preterm babies were Tamils and majority were Hindus $(72.3 \%)$ and the rest were Christians which is due to the population distribution in the Jaffna district, where the majority $(83 \%)$ of people are Hindus ${ }^{21}$. Usually, in Jaffna, it is common to have children after the marriage, which is also common in the rest of the country as well, due to cultural and traditional values of the country. It is supported by this study as only $1.2 \%(n=2)$ of the mothers were unmarried and delivered babies. However, none of the unmarried mothers of Jaffna district delivered preterm babies in very preterm gestation (Table 4), which is similar to mothers from the rest of the country $^{22}$. These findings lead to the conclusion that unmarried mothers do not have a positive correlation with the risk of having preterm babies. However, marital status was considered a risk factor among mothers from other countries ${ }^{15,20}$.

Considering the educational level, all mothers of preterm babies had studied up to grade five, while among mothers who delivered very preterm babies $(n=14)$, majority $(n=10)$ had school education below Grade 12. However, higher educational level of mothers had no influence on preterm birth $^{23}$, while preterm births increased among highly educated mothers ${ }^{24}$. Further, no significant association was found between education and gestation $(p=0.486)$ (Table 3$)$, similar to mothers in other countries ${ }^{5,15}$. These findings indicate that school education is insufficient to give information on preterm delivery, while there had been great impact on mothers by advice provided by antenatal clinics conducted by the Medical Officer of Health $(\mathrm{MOH})$ on healthcare during pregnancy

Majority $(86.1 \%)$ of mothers were housewives in this study. Among employed mothers, 91.7\% $(\mathrm{n}=22)$ were aged between 20-34 years, while $89.5 \% \quad(n=17)$ of over aged mothers were housewives. Results indicate that employment was not the reason for delaying pregnancy in the Jaffna district. Maternal employment including standing, repetitive bending, climbing stairs, lifting heavy objects, etc. during pregnancy can cause placental abruption and results in preterm delivery ${ }^{25}$. Such 
tasks are commoner among self-employed mothers and housewives. However, in the present study it was observed that maternal employment had no significant influence on gestational age of preterm birth (Table 3), similar to other studies ${ }^{26,27}$. However, working mothers in industrial countries $^{5,15,28}$ had increasing risk of preterm birth due to exposure of mothers to unsafe material.

Inequality of family income affects health services obtained during pregnancy from private and government sectors. The poverty line in Jaffna district for 2017 was LKR 4340 (23.54 USD) ${ }^{29}$, while mothers with low financial status use available resources such as nutritious food, treatment, frequent visit to clinics, and maternal stress as well ${ }^{30}$. In this study, majority $(37.6 \%)$ of the mothers received total monthly income of LKR $15,000-19,999$, and lowest frequency $(3.5 \%)$ of the mothers were getting LKR below 5,000, while mean monthly household income was LKR 18, 917 in 2009/ 2010 in Jaffna district of Sri Lanka ${ }^{31}$. Further, the range of total monthly income per person was in wide range, i.e. between 833 to 8,750 LKR. However, no significant association was found between total monthly income and gestational age, similar to other studies ${ }^{5,27}$. Such observations among mothers in this study could be due to the free 'Mother and Baby Care' services provided during antenatal period in Sri Lanka by the Medical Officer of Health (MOH) and Government hospitals, and family members might help the mothers not financially but also in some other ways, i.e. maintaining vegetables garden for food/ rearing household animals; that is why those mothers were able to live with such total monthly income as they reported and mentioned in Table 2.

Majority $(75.7 \%)$ of mothers were living in extended families (Table 2), showing the tradition of the Jaffna district community, and the extended family had provided better pregnant care, similar to another Asian country, Pakistan ${ }^{27}$. Although there was a significant shift from extended families to a nuclear family system in Sri Lanka ${ }^{31}$, this was not observed among mothers selected for this study. Interestingly, in Jaffna district, majority of teenaged ( 5 mothers out of 8$)$ and over aged (15 mothers out of 19) mothers were living in extended families, may be to have better pregnancy care. Further, among employed mothers $(n=24)$ too, $95.8 \%$ were living in extended families so as to continue the job during pregnancy. In addition, the family set up of mothers from Jaffna district did not have an impact on preterm delivery and no significant relationship (Table 3).

Among mothers receiving the lowest income $(n=65), 87.7 \% \quad(n=57)$ were attached to extended families. Total monthly household income between
LKR 10,000-14,999 of mothers living in nuclear family was $11.6 \%$, while it was between LKR 15,000- 19,999 among 40.4\% of mothers attached to extended families. However, other members of those extended families might help the mothers not financially but in some other way, i.e. individual support to maintain pregnancy health/ maintaining vegetables garden for food/ rearing household animals. Besides, Ministry of Health, Sri Lanka issued nutritious foods for pregnant mothers, named "National Nutrition Program for pregnant mothers". Hence, mothers from Jaffna district were able to live with such total monthly income.

\section{Conclusions}

Maternal socio-demographic and economic factors had no significant influence on preterm deliveries in the Jaffna district of Sri Lanka.

\section{Acknowledgements}

We thank the National Science Foundation (NSF), Sri Lanka for financial support. The support of mothers of the preterm babies is acknowledged.

\section{References}

1. WHO fact sheet on preterm birth, Available at: https://www.who.int/newsroom/fact-sheets/detail/preterm-birth, 2018 [Accessed 20 May. 2020].

2. Chartsbin.com. Preterm birth rate by Country. Available at: http://chartsbin.com/view/34987, 2017 [Accessed 20 May. 2020].

3. Aragao VMF, Silva AAM, Aragao LF, Barbieri MA, Bettiol H, Coimbra LC, et al. Risk factors for preterm births in Sao Luis, Brazil. Reports in Public Health 2004; 20(1): 57-63. https://doi.org/10.1590/S0102311X20040 00100019

PMid: 15029304

4. UN Inter-agency group for child mortality estimation, Mortality rate, under5(per1,000livebirths, Available at: https://data.worldbank.org/Indicator/SH.D YN.MORT?end=2016\&locations $=$ LK\&st art $=1975 \&$ view $=$ chart, 2017 [Accessed 23 Oct. 2017].

5. Daniel WW. Biostatistics: a foundation for analysis in the health sciences. $7^{\text {th }}$ Ed. New York: John Wiley \& Sons. 1999.

6. Kiridana V, Wickremasinghe N. An observational study on retinopathy of prematurity in the neonatal intensive care 
unit at Teaching Hospital, Peradeniya, Sri Lanka. Sri Lanka Journal of Child Health 2010; (39): 49.

https://doi.org/10.4038/sljch.v39i2.1957

7. Demographic and Health Survey, Sri Lanka. Available at:

http://www.statistics.gov.lk/social/DHS_2 016a/DHS_presentations/Key\%20Finding s.pdf,2016 [Accessed on 19 May. 2020]

8. De Jong M, Verhoeven M., Lasham CA, Baar ALV. Behaviour and development in 24 month old moderately preterm toddlers. Archives of Disease in Childhood 2015; 100: 548-53.

https://doi.org/10.1136/archdischild-2014307016

PMid: 25589560

9. Ahn SH, Kim SA. Assessment of preterm infants using Bayley-III scales in Korea. Annual Rehabilitation Medicine 2017; 41(5): 843-50.

https://doi.org/10.5535/arm.2017.41.5.843

PMid: 29201824 PMCid: PMC5698672

10. Johnson S, Evans TA, Draper ES, Field DJ, Manktelow BN, Marlow $\mathrm{N}$, et al. Neuro developmental outcomes following late and moderate prematurity: a population-based cohort study. Archives of Diseases of Childhood. Fetal and Neonatal Edition 2015; 100: 301- 8. https://doi.org/10.1136/archdischild-2014307684

PMid: 25834170 PMCid: PMC4484499

11. Kamalarupan L, Sivapalan K, Sivarajah N, Surenthirakumaran R. Factors affecting the early initiation of breast feeding at birth in the Jaffna Municipal Council area, Master of Philosophy Thesis in Nursing, Submitted at University of Jaffna, 2014.

12. Jayakody H, Senarath U, Attygalle D. Health related quality of life of preterm born children at three years in a suburban district in Sri Lanka: retrospective cohort study, BMC Paediatrics 2018; 18(1): 193. https://doi.org/10.1186/s12887-018-11623

PMid: 29907147 PMCid: PMC6004082

13. Marsson I; Gender aspects of preterm birth. British Journal of Obstetrics and Gynaecology 2003; 110(20): 34-8. https://doi.org/10.1046/j.14710528.2003.0 0022.x
14. Burguet A, Kaminski M, Abrahma-Lerat L, Schaal JP, Cambonie G, Fresson J, et al. The complex relationship between smoking in pregnancy and very preterm delivery. British Journal of Obstetrics and Gynaecology 2004; 11(3): 258-65. https://doi.org/10.1046/j.14710528.2003.0 0037.x

PMid: 14961888

15. Edward D, Emond A, Whitelaw A. Long term cognitive outcomes of infants born moderately and late preterm, Developmental Medicine and Child Neurology 2012; 54: 704-9. https://doi.org/10.1111/j.14698749.2012.0 4315.x PMid: 22616920

16. James WH; Why are boys more likely to be preterm than girls? Plus other related conundrums in human reproduction. Human Reproduction 2000; 15: 2108-11. https://doi.org/10.1093/humrep/15.10.210 8

PMid: 11006182

17. Dolgun ZN, Inan C, Altintas S, Okten SB, Sayin, NC. Preterm birth in twin pregnancies: Clinical outcomes and predictive parameters, Pakistan Journal of Medical Sciences 2016; 32(4): 922-6. https://doi.org/10.12669/pjms.324.10409 PMid: 27648040 PMCid: PMC5017103

18. childrenshospital.org. Low birth weight in newborns | Symptoms and causes. Available at:

http://www.childrenshospital.org/conditio ns-and-treatments/conditions//lowbirthweight-in-newborns/symptoms-andcauses. 2020 [Accessed 20 May. 2020].

19. Kamburova MS, Georgieva SL, Un M; Marital status and health of the mother as risk factors for premature birth in Pleven, Bulgaria. International Journal of Health Administration and Education Congress 2016; 2: 53-62.

https://doi.org/10.12738/SM.2016.1.0014

20. Department of Census and Statistics, Sri Lanka. Census of Population and housing. Available at: http://www.statistics.gov.lk/PopHouSat/C PH2011/Pages/Activities/Reports/CPH_20 12 5Per_Rpt.pdf. 2012 [Accessed 19 May. 2020]. 
21. Sayed AM, Galea S. Changes in the relationship between marriage and preterm birth, 1989-2006, Public Health Report 2011; 126(5): 717-25.

https://doi.org/10.1177/003335491112600

514

PMid: 21886332 PMCid: PMC3151189

22. Auger N, Abrahamowicz M, Park AL, Wynant W. Extreme maternal education and preterm birth: Time-to-event analysis of age and activity- dependent risks. Annual Epidemiology 2013; 23(1): 1-6. https://doi.org/10.1016/j.annepidem.2012. 10.007

PMid: 23176780

23. EI-Sayed AM, Galea S. Temporal changes in socio-economic influences on health: Maternal education and preterm birth. American Journal of Public Health 2012; 102(9): 1715-21. https://doi.org/10.2105/AJPH.2011.30056 4

PMid: 22742063 PMCid: PMC3482027

24. Khojasteh F, Arbabisarjou A, Boryri T, Safarzadeh A, Pourkahkhaei M. The relationship between maternal employment status and pregnancy outcomes. Global Journal of Health Science 2016; 8(9): 37- 43. https://doi.org/10.5539/gjhs.v8n9p37 PMid: 27157153 PMCid: PMC5064079

25. Saurel-Cubizolles M, Zeitlin J, Lelong N, Papiernik E, Di R, Breart G; Employment, working conditions, and preterm birth: results from the Euro pop case-control survey, Journal of Epidemiology and Community Health 2004; 58(5): 395-401. https://doi.org/10.1136/jech.2003.008029 PMid: 15082738 PMCid: PMC1732750

26. Shaikh K, Premji SS, Rose MS, Kazi A, Khowaja S, Tough S. The association between parity, infant gender, higher level of paternal education and preterm birth in Pakistan: a cohort study. BMC Pregnancy and Childbirth 2011; 11: 88.

https://doi.org/10.1186/1471-2393-11-88

PMid: 22047209 PMCid: PMC3239291
27. Di Renzo GC, Giardina I, Rosati A, Clerici G, Torricelli M, Petraglia F. Maternal risk factors for preterm birth: A country-based population analysis, European Journal of Obstetrics Gynaecology and Reproductive Biology 2011; 159(2): 342-6. https://doi.org/10.1016/j.ejogrb.2011.09.0 24

PMid: 22036591

28. Department of Census and Statistics, Sri Lanka, Available at: http://www.statistics.gov.lk/.2019 [Accessed 18 May. 2020].

29. Wallace ME, Mendola P, Chen Z, Hwang, BS, Grantz, KL. Preterm birth in the context of increasing income inequality. Maternal and Child Health Journal 2016; 20(1): 164-71. https://doi.org/10.1007/s10995-015-18169

PMid: 26450504 PMCid: PMC6211180

30. Household income and Expenditure Survey Report of Ministry of Finance and Planning, Sri Lanka. Available at: https://catalog.ihsn.org/index.php/catalog/ 6086. 2012 [Accessed 18 May. 2020]

31. Weeratunga MK, Graeme H; Changing family structure in Sri Lanka, Sri Lanka Journal of Population Studies 2014; 14: 95-114. 